
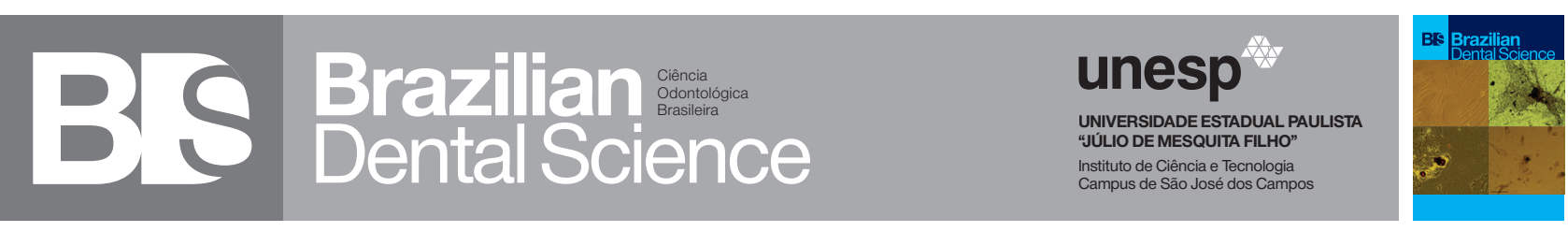

\title{
Assessing the quality of root canal filling and instrumentation time using kedo-s files, reciprocating files and k-files
}

Avaliando a qualidade de obturação e tempo instrumentação usando limas kedo-s, limas reciprocantes e limas k manuais

Lakshimi LAKSHMANAN ${ }^{1}$, Geo MANI ${ }^{1}$, Ganesh JEEVANANDAN $^{1}$, Vignesh RAVINDRAN ${ }^{1}$, Subramanian ERULAPPAN MUTHU GANAPATHI ${ }^{1}$

1 - Department of Pediatric and Preventive Dentistry - Saveetha Dental College and Hospitals - Saveetha Institute of Medical and Technical Sciences - Chennai - Tamil Nadu - India.

\begin{abstract}
Objective: Pulpectomy is the conservative treatment approach that retains and preserves the primary tooth in the dental arch in its normal function and non-pathologic state until its exfoliation. Over the years, pulpectomy has been performed using various instrumentation techniques. The aim of this study was to compare the quality of root filing and instrumentation time using Kedo-S files, Reciprocating files and K-files in primary teeth. Material And Methods: A randomized clinical trial was performed on 45 primary molars equally distributed for instrumentation with Kedo-S files, reciprocating files and K-Files. Immediate post-operative digital radiographs were taken to evaluate the quality of root filing and root canal instrumentation time was also recorded. Results: Mean instrumentation time with Kedo-S was 75.6 seconds, reciprocating file was 190.6 seconds and K-file was 95.4 seconds. Highest optimal fill was obtained with Kedo-S file group, highest overfill was obtained with Kedo-S group and highest under fill was obtained with reciprocating file group. Conclusion: Kedo-S rotary system provides better quality of root canal filling in minimum instrumentation time.
\end{abstract}

\section{KEYWORDS}

Pulpectomy; Primary teeth; Root canal filling; Rotary files.

\section{RESUMO}

Objetivo: A pulpectomia é o tratamento conservador que retém e preserva o dente decíduo na arcada dentária em sua função normal e estado não patológico até sua esfoliação. Ao longo dos anos, a pulpectomia foi realizada usando várias técnicas de instrumentação. $\mathrm{O}$ objetivo deste estudo foi comparar a qualidade da obturação do canal radicular e do tempo de instrumentação usando limas Kedo-S, limas reciprocantes e limas $\mathrm{K}$ em dentes decíduos. Material e Métodos: Foi realizado um ensaio clínico randomizado em 45 molares decíduos distribuídos igualmente para instrumentação com limas Kedo-S, limas reciprocantes e limas K. Radiografias digitais pós-operatórias imediatas foram realizadas para avaliar a qualidade da obturação e também foi registrado o tempo de instrumentação do canal radicular. Resultados: O tempo médio de instrumentação com Kedo-S foi de 75,6 segundos, com limas reciprocantes foi de 190,6 segundos e com limas K foi de 95,4 segundos. O maior índice de obturação ideal foi obtido com o grupo de limas Kedo-S, o maior índice de sobreobturação foi obtido com o grupo Kedo-S e o maior índice de infraobturação foi obtido com o grupo de limas reciprocantes. Conclusão: $\mathrm{O}$ sistema rotatório Kedo-S fornece melhor qualidade de obturação do canal radicular em tempo mínimo de instrumentação.

\section{PALAVRAS-CHAVE}

Pulpectomia; Dentes decíduos; Obturação do canal radicular; Limas rotatórias. 


\section{INTRODUCTION}

$\mathrm{P}$ ulpectomy is the choice of treatment for primary teeth with chronic inflammation or necrosis in the radicular pulp, thereby retaining the primary teeth in the oral cavity until its physiological exfoliation and as an alternative to extraction and space maintenance [1]. It is the procedure involving complete removal of pulp tissue from the canals in primary teeth followed by filling it with a resorbable material. The bio mechanical preparation (BMP) of the canals play a major role in determining the success of pulpectomy [2]. The goal of root canal preparation is to remove all the necrotic and vital organic tissues from the canal system, and to shape the canals in such a way that it allows easy debridement and placement of root fillings of high quality [3].

The canal preparation in primary teeth using hand instruments is challenging, time consuming and can result in iatrogenic errors [4]. Barr et al determined that the BMP in primary teeth using Ni-Ti rotary files were faster, cost effective and resulted in predictable fillings [5]. Various other studies have stated that the $\mathrm{Ni}$-Ti rotary files reduced the extrusion of debris in apical region $[6,7]$. The use of rotary files in primary teeth resulted in more conical shaped root canals and provided considerable dentin removal thereby ensuring adequate root canal cleaning, easy insertion and compaction of the material than those prepared with manual files despite the material used [8,9]. A survey conducted among Indian dentists stated that about $50 \%$ of them preferred rotary systems for performing pulpectomy and reduction in instrumentation time was the prime reason for their preference [10].

Kedo-S file system (Reeganz Dental Care Pvt. Ltd. India) is an exclusive pediatric single file rotary system consisting of D1, E1 and U1 files. The total length of the files is $16 \mathrm{~mm}$ and the length of cutting flutes is $12 \mathrm{~mm}$. It has variably variable taper (4-8\%) with varying tip diameter (D1-0.25, E1-0.30 and U1-0.40) corresponding to its use in primary teeth [11].
Reciprocating motion of files improves flexibility of the files, which can adapt better to the curved and tortuous canals thereby providing better cleaning efficacy. Instead of a rotary motion, the reciprocating files work in a reverse 'balanced force' cutting motion and are driven by a pre-programmed motor that turns the files in a back and forth 'reciprocating motion' $[12,13]$.

The purpose of this study was to compare the quality of root canal filling and instrumentation time in primary teeth using Kedo-S files, Reciprocating files and $\mathrm{K}$ files.

\section{MATERIAL AND METHODS}

This randomized clinical trial was conducted in the Department of Pediatric and Preventive dentistry in a dental institute. The ethical approval for the study was obtained from the Institutional review board (SRB/ MDS/PEDO/18-19/0014). Participation in the study was voluntary and informed consent was obtained from all the parents/ guardians/ caretakers before starting the treatment.

\section{selection}

Sample size estimation and participant's

Based on data from previously published studies, the sample size of 45 was obtained with $95 \%$ power using a power analysis. Inclusion criteria were as follows: (1) Children with good health requiring pulpectomy in any of the primary mandibular molars; (2) vital or nonvital pulp without a sinus tract; (3) presence of enough coronal structure and minimum of $2 / 3 \mathrm{rd}$ root structure; (4) absence of perforation in the furcation area; (5) absence of mobility; (6) internal or external pathological root resorption.

Based on a computer-generated randomization method, the selected teeth were randomly allocated to the three groups and instrumentation was done using:

Group A (15 teeth): Kedo-S rotary file D1, E1 (Reeganz Dental Care Pvt. Ltd. India),

Group B (15 teeth): Ni-Ti K-flex file (Mani, Tochigi, Japan) coupled with NSK endodontic 
contra-angle reciprocating hand piece (TEPE10R, Nakanishi Inc.)

Group C (15 teeth): Conventional K-files (Mani, Inc, Tochigi, Japan).

\section{Clinical procedure}

Single visit pulpectomy was performed by a single operator (pediatric dentist) who was well-trained in using the different file systems that are used in the current study. Pre-operative digital intraoral periapical radiograph of the teeth indicated for pulpectomy were taken prior to the start of the procedure. The teeth were anesthetized with $2 \%$ Lignocaine with $1: 2,00,000$ adrenaline (LOX* $2 \%$ adrenaline, Neon Laboratories limited India) and isolated using rubber dam (GDC marketing, India). No.6 round bur was used in a high-speed hand piece for removing the caries and access opening. No.330 pear-shaped bur was used to completely de-roof the pulp chamber. N0.10 size K-file was used to determine the canal patency. Working length was determined with preoperative radiograph using Ingle's method and confirmed with radiograph.

The biomechanical preparation was done using the following systems:

Group A ( $\mathrm{N}=15)$ : The canals were instrumented using Kedo-S pediatric rotary files (Reeganz Dental Care Pvt. Ltd. India). The mesial canals were instrumented with D1 files and distal canals were instrumented with E1 files till the working length with an X-Smart endodontic motor (Dentsply Maillefer, OK, USA) at $300 \mathrm{rpm}$ and $2.2 \mathrm{~N} \mathrm{~cm}$ torque.

Group B $(\mathrm{N}=15)$ : The canals were instrumented in sequence using No.15 to 30 K-file, which was coupled with NSK Endodontic contra-angle Reciprocating hand piece (TEPER10, Nakanishi Inc.).

Group C $(\mathrm{N}=15)$ : The canals were instrumented using a quarter-turn pull technique with Hand K-files (Mani, Inc, Tochigi, Japan). The mesial canals were instrumented till 30 size and the distal canals were instrumented till 35 size up to the working length.
A new file was used for every tooth in order to maintain uniformity during canal preparation. The canals were irrigated with $1 \%$ sodium hypochlorite between each file followed by irrigation with normal saline. The root canals were then dried using paper points and root canals were filled with Metapex (Meta Biomed Co. Ltd. Chungbuk, Korea). The teeth were then permanently restored using type II Glass ionomer cement (GC, India) and stainless steel crown was luted with type I glass ionomer cement (GC, India) on the same appointment.

Assessment of instrumentation time and quality of obturation

The instrumentation time was recorded in seconds using a stopwatch by a trained dental assistant which included only the total active instrumentation period of the files. A postoperative radiograph was taken to evaluate the quality of root canal filling using the criteria laid down by Coll and Sadrian (1996) as Underfilled (canals with metapex more than $2 \mathrm{~mm}$ short of apex); Optimal (metapex ending at radiographic apex/ upto $2 \mathrm{~mm}$ short of apex); Overfilled (canals with metapex outside the root). The evaluation of post-operative radiographs were done by a senior faculty who was blinded from the file system used. [Figure I] represents the immediate post-operative radiographs depicting different quality of root canal filling (under fill, optimal fill, over fill).

\section{Statistical Analysis}

The data were entered and analyzed using SPSS software version 17.0 (SPSS Inc., Chicago, IL, USA). The instrumentation time between the three groups were compared using ANOVA test followed by Tukeys post-hoc analysis to list out the significant groups. Chi square test was used to assess the quality of root canal filling in the primary molars. The $\mathrm{p}$-value of less than 0.05 was considered statistically significant. 

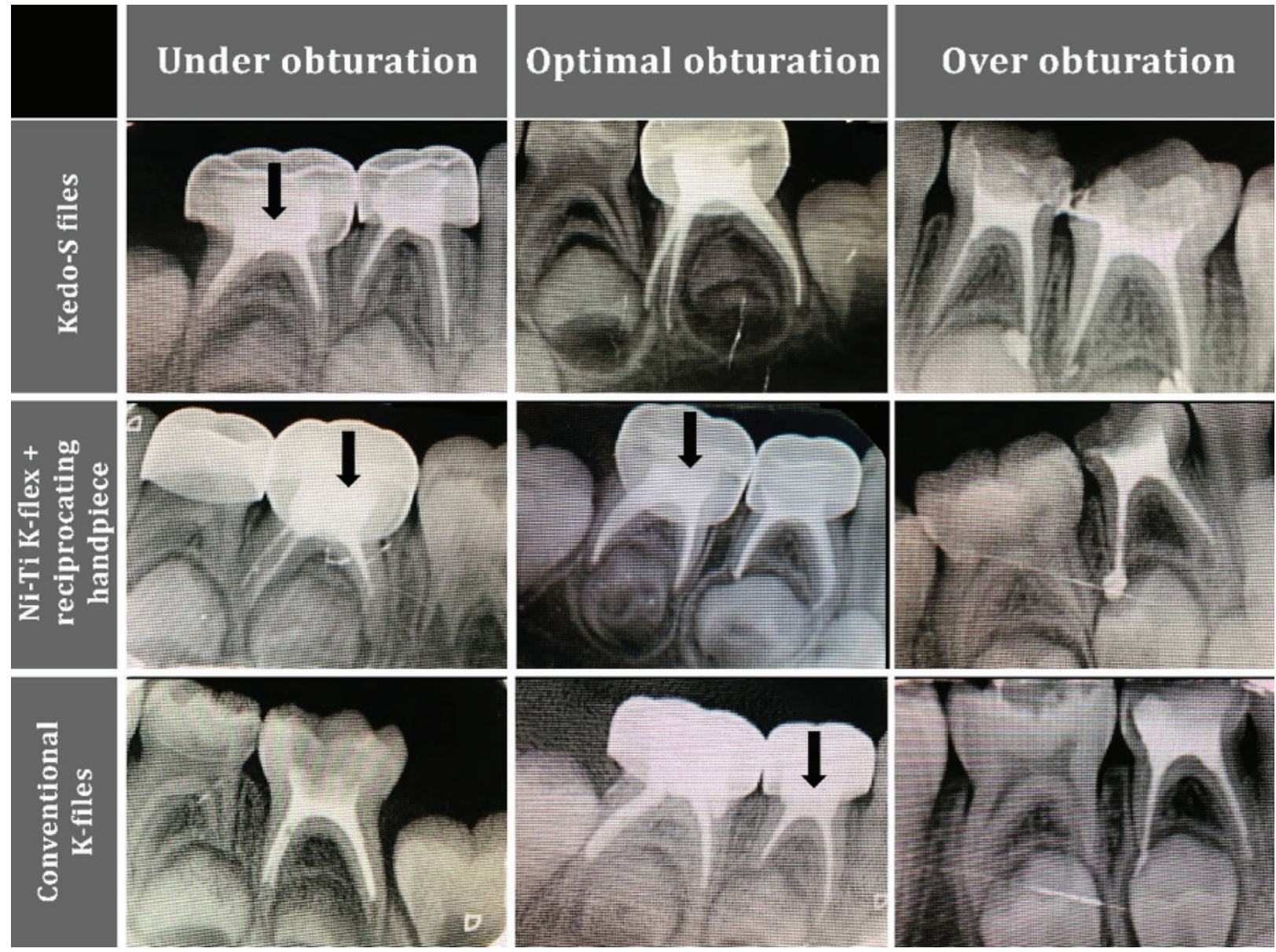

Figure 1 - Immediate post-operative radiographs showing different quality of root canal filling in all three groups- (a) Under fill, (b) Optimal fill, (c) Over fill.

\section{RESULTS}

A total of 45 children were included in the study, among which 21 were males and 24 were females with mean age of $6.06+1.25$ years [Table I].

Table I-Demographic variables describing sample size, age (mean + standard deviation) and gender of participants in the study

\begin{tabular}{|cccc|}
\hline $\begin{array}{c}\text { Treatment } \\
\text { group }\end{array}$ & Sample size & $\begin{array}{c}\text { Age } \\
\text { (Mean + Stan- } \\
\text { dard deviation) }\end{array}$ & $\begin{array}{c}\text { Gender } \\
\text { (Male/Female) }\end{array}$ \\
\hline Kedo-S files & 15 & $5.93+1.38$ & $8 / 10$ \\
\hline Reciprocating files & 15 & $6.06+1.27$ & $8 / 6$ \\
\hline K-files & 15 & $6.20+1.14$ & $5 / 8$ \\
\hline
\end{tabular}

The mean instrumentation time was found to be highest for reciprocating file group (190.6 seconds) and least for Kedo-S file group (75.6 seconds). The mean instrumentation time for $\mathrm{K}$ files was (95.4 seconds). A statistically significant difference was obtained when subjected to ANOVA test $(\mathrm{p}<0.001)$ [Table II].

Table II - Comparison of instrumentation time (in seconds) among the three groups

\begin{tabular}{ccccc}
\hline Group & $\mathbf{n}$ & Mean & Standard deviation & Overall p-value \\
\hline Kedo-S files & 15 & 75.6 & 9.8 & $<0.001($ sig) \\
Reciprocating files & 15 & 190.6 & 10.2 & \\
\hline K-files & 15 & 95.4 & 12.7 & \\
Total & 45 & 120.5 & 51.8 & \\
& \\
ANOVA test, $p<0.05$ & & \\
*Statistically significant values
\end{tabular}


On intergroup comparison based on Tukeys post-hoc test, statistically significant differences were obtained when each group was compared with the other two groups [Table III].

Table III - Intergroup comparison of instrumentation time among the groups

\begin{tabular}{|ccc|}
\hline Groups & \multicolumn{1}{c}{ Groups } & P-value \\
\hline Kedo-S files & $\begin{array}{c}\text { Reciprocating files } \\
\text { K-files } \\
\text { Kedo-S files } \\
\text { Kfiles } \\
\text { Reciprocating files }\end{array}$ & $<0.001($ sig) \\
\hline K-files & $\begin{array}{c}\text { Kedo-S files } \\
\text { Reciprocating files }\end{array}$ & $<0.001($ sig) \\
\hline
\end{tabular}

Tukey Post Hoc test, $\mathrm{p}<0.05$

*Statistically significant

On assessing the quality of root canal filling, the highest optimal filling was noted with Kedo-S group (60\%) followed by K-files (27\%) and Reciprocating files (20\%). The group which showed highest over fill was Kedo-S (27\%) and highest under fill was Reciprocating files (60\%) [Table IV]. Intergroup comparison between the three groups showed no significant differences $(\mathrm{p}=$ 0.07).

Table IV - Comparison of quality of root canal filling between the groups

\begin{tabular}{|ccccc|}
$\begin{array}{c}\text { Assessment } \\
\text { of quality of } \\
\text { obturation }\end{array}$ & $\begin{array}{c}\text { Kedo-S } \\
\text { files }\end{array}$ & $\begin{array}{c}\text { Reciprocating } \\
\text { files }\end{array}$ & K-files & $\begin{array}{c}\text { Overall } \\
\text { p-value }\end{array}$ \\
\hline Under fill & $2(13 \%)$ & $9(60 \%)$ & $8(53 \%)$ & $0.07(\mathrm{NS})^{\star}$ \\
\hline Optimal fill & $9(60 \%)$ & $3(20 \%)$ & $4(27 \%)$ & \\
\hline Over fill & $4(27 \%)$ & $3(20 \%)$ & $3(20 \%)$ & \\
\hline
\end{tabular}

Chi square test, $p<0.05$

*Not statistically significant values

\section{DISCUSSION}

Pulpectomy is done to treat the infected teeth and maintain it in the dental arch as natural space maintainer, provided they can be restored to function and remain free from the disease [1]. The rationale of the procedure includes chemical and mechanical removal of irreversibly inflamed or necrotic radicular pulp tissue, followed by root canal filling with an inert resorbable material [14]. An efficient chemo-mechanical preparation is essential for effective canal disinfection and thereby contributes to the success of the endodontic treatment. This can be achieved by using appropriate irrigants and a good file system.

Conventional hand file system has been used for decades and are considered the gold standard in the field of pediatric endodontics. But the disadvantage is that they are time consuming, which plays a major in the aspect of behavior management in pediatric dentistry. The preparation of curved root canals with hand files frequently results in undesirable aberrations such as elbows, zips and danger zones [15].

In recent years, endodontic instruments have undergone various modifications to attain the better cleaning and shaping efficacy [11]. Introduction of rotary systems in the area of pediatric endodontics made a paradigm shift by providing better quality of obturation and reduction in treatment time [5]. Ni-Ti rotary system has gained popularity because of advantages such as decreased preparation time, minimization of procedural errors, and promotion of a more uniform filling [16]. The flexibility and design of the files allows them to closely follow the original root canal path. The tortuous and irregular canal walls are effectively cleaned with Ni-Ti rotary files since the clockwise motion of the files pulls the pulp tissue and dentin out of the canal as files are engaged [5]. Rotary instrumentation in primary teeth provided conical-shaped canals and reduced the instrumentation time. In addition, the flexibility of Ni-Ti rotary files 
enables the practitioner to use the files with greater confidence in curved primary canals [17]. Ni-Ti files designed for permanent teeth have been used for pulpectomy in primary teeth [18]. Primary teeth have softer root dentin, short, thin and curved roots with undetectable root resorption and ribbon shaped root morphology $[2,19]$.

In a survey conducted among Indian dentists, $26 \%$ of the practitioners experienced instrument breakage in the primary root canals and $66 \%$ of them felt that an exclusive pediatric rotary file should be used in primary teeth [10]. So Kedo-S rotary file system was preferred in the current study, which is the only patented file system for use in primary teeth.

Reciprocating files works by back and forth motion that reduces the number of endodontic mishaps through instrument separation, thereby improving the safety of the shaping procedures [20]. Prabhakar et al, stated that the reciprocating single file system were faster and safer for canal preparation as the reciprocating motion does not over engage the dentin and reaches the working length faster than rotational motion [21]. The other advantages being better flexibility and reduced time when compared to hand files. In the current study, K-files were coupled to NSK reciprocating hand piece (TEP-E10R, Nikanishi Inc.) powered by an electric motor (Endo Plus driller, VK driller, SP, Brazil) to stimulate the reciprocating motion.

The present study compared the quality of root canal filling and instrumentation time of Kedo-S rotary system, reciprocating file system and conventional K-files. With respect to the quality of obturation, optimal filling was highest using Kedo-S rotary system followed by hand K-files and reciprocating file system. There was no statistically significant difference noticed among the three groups. A superior quality of root canal filling was observed in Kedo-S rotary files group which was similar to a study conducted by Jeevanandan $G$ et al., who reported $77 \%$ optimal filling with
Kedo-S rotary files [22]. Kedo-S files with progressively increasing taper results in higher cervical enlargement and restricted apical preparation which can be the reason for better quality of root canal filling. In addition to this, the increased flexibility of the file aids in adaptation to the primary canal curvature, unlike K-files that results in increased zipping and transportation [22].

A statistically significant reduction was noticed in the instrumentation time on using Kedo-S rotary file system (75.6 s) for canal preparation in primary teeth when compared to manual (95.4 s) and reciprocating files system (190.6 s). The results are in accordance with the studies done by Barr et al., OchoaRomero et al., using adult rotary file system and Jeevanandan $G$ et al, using pediatric rotary system $[5,22,23]$. The probable reason for minimal instrumentation time with Kedo-S rotary system is that each canal is prepared with one file whereas, manual and reciprocating file system requires sequential preparation with 15 to 30 or 35 size files in each canal.

Clinically, the reduced instrumentation time considerably improves patient cooperation and lessens fatigue of the operator. However, long term follow up is required to evaluate the clinical and radiographic success of the pulpectomy performed using different instrumentation techniques.

\section{CONCLUSION}

The rotary system used in the present study provided a better quality of root canal filling and reduced instrumentation time than reciprocating and manual instrumentation techniques.

\section{Financial support and sponsorship} Nil.

\section{Conflicts of interest}

There are no conflicts of interest. 


\section{REFERENCES}

1. Pinkham JR, Casamassimo PS. Pediatric dentistry. Infancy through adolescence. 4th ed. Philadelphia:WB Saunders; 2005. p.390.

2. Fuks AB. Current concepts in vital primary pulp therapy. Eur J Paediat Dent 2002;3(3):115-20

3. Haapasalo M, Endal U,Zandi H, Coll JM. Eradication of endodontic infection by instrumentation and irrigation solutions. Endod Topics. 2005;10(1):77-102

4. Silva La, Leonardo MR, Nelson-Filho P, Tanomaru JM. Comparison of rotary and manual instrumentation techniques on cleaning capacity and instrumentation time in deciduous molars. J Dent Child. 2004;71(1):45-7.

5. Barr ES, Kleier DJ, Barr NV. Use of nickel-titanium rotary files for root canal preparation in primary teeth. Pediatr Dent. 1999 Nov-Dec;21(7):453-4

6. FerrazCC, Gomes NV, Gomes BP,Zaia AA, et al. Apical extrusion of debris and irrigants using two hand and three engine-driven instrumentation techniques. IntEndod J 2001;34(5):354-8.

7. Selvakumar H, Kavitha S, ThomasE, Anadhan V,Vijayakumar R. Computed tomographic evaluation of $\mathrm{K} 3$ rotary and stainless steel $\mathrm{K}$ file instrumentation in primary teeth. JClin Diagn Res. 2016; 10(1):ZC05-8. doi:10.7860/ JCDR/2016/14183.7028.

8. Crespo S, Cortes 0 , Garcia C,Perez L.Comparison between rotary and manual instrumentation in primary teeth. JClin Pediatr Dent. 2008;32(4):295-8.

9. Govindaraju L, Jeevanandan G, Subramanian E. Knowledge and practice of rotary instrumentation in primary teeth among Indian dentists: a questionnaire survey.J Jnt Oral Health. 2017;9:45-8.

10. Jeevanandan G. Kedo S paediatric rotary files for root canal preparation in primary teeth-case report. JClin Diagn Res. 2017;11(3):ZRO3-ZRO5. doi: 10.7860/JCDR/2017/25856.9508.

11. Sotokawa T. An analysis of clinical breakage of root canal instruments. J Endod 1998; 14:75-82

12. Varela-Patino P,Martin BiedmaB, Rodriguez N, Cantatore G, Malentaca A, RuizPinon M. Fracture rate of nickel-titanium instruments using continuous verses alternating rotation. Endodontic Practice Today 2008;2(3):193-7.
13. Machida Y.Root canal obturation in primary teeth: a review. Jap Dent Assoc J. 1983; 36:796-802

14. Hulsmann M,Schade M,SchafersF.A comparative study of root canal preparation with HER0 642 and Quantec SC rotary Ni-Ti instruments. Int Endod J. 2001;34(7):538-46.

15. Azar MR, Mokhtare M. Rotary Mtwo system versus manual K-file instruments: efficacy in preparing primary and permanent molar root canals. Indian J Dent Res 2011;22(2):363. doi:10.4103/-970-9290.84283.

16. Govindaraju L, Jeevanandan G, Subramanian EM. Comparison of quality of obturation and instrumentation time using hand files and two rotary file systems in primary molars: a single-blinded randomized controlled trial. Eur J Dent 2017;11(3):376-9.Doi:10.4103/ejd.ejd 34516.

17. Nagaratna PJ, Shashikiran ND, Subbareddy VV. In vitro comparison of $\mathrm{Ni}$-Ti rotary instruments and stainless steel hand instruments in root canal preparations of primary and permanent molar. J Indian Soc Pedod Prev Dent 2006;24(4):186-91

18. Finn SB. Morphology of primary teeth. In: Finn SB. Clinical pedodontics. 4th ed. Philadelphia: Saunders; 1973. p.59-70.

19. BeruttiE, Chiandussi G, Paolino DS, Scottin N, Cantatore G, Castellucci A, etal. Canal shaping with wave one primary reciprocating files and protaper system. JEndod. 2012;38(4):505-9.

20. Prabhakar AR, Yavagal C, DixitK, Naik SV. Reciprocating vs rotary instrumentation in pediatric endodontics: cone beam computed tomographic analysis of deciduous root canals using two single-file systems. Int JClin Pediatr Dent. 2016 Jan-Mar;9(1):45-9. doi:10.5005/jp-journals-10005-1332.

21. Jeevandhan G, Govindaraju L.Clinical comparison of Kedo-S paediatric rotary files vs manual instrumentation for root canal preparation in primary molars: a double blinded randomised clinical trial. Eur Arch Paediatr Dent2018;19(4):2738. Doi:10.1007/s40368-018-0356-6.

22. Ochar-Romero T,Mendez-Gonzalez V, Flores-Reyes H, Pozos-Guillen A. Comparison between rotary and manual techniques on duration of instrumentation and obturation times in primary teeth.J Clin Pediatr Dent 2011;35(4):359-63

\section{Vignesh R}

\section{(Corresponding address)}

Senior lecturer

Department of Pediatric and Preventive Dentistry, Saveetha Dental College and

Hospitals, Saveetha Institute of Medical and Technical Sciences,

162, Poonamallee High Road, Chennai-600 077, Tamil Nadu, India.

Date submitted: 2019 Jul 10

E-mail: na.soufer@hotmail.com 